\title{
25. METASOMATIC GARNETS IN CALCITE (MICARB) CHALK AT SITE 251, SOUTHWEST INDIAN OCEAN
}

\author{
D. R. C. Kempe and A. J. Easton, Department of Mineralogy, British Museum (Natural History), London, England
}

\begin{abstract}
An occurrence of metasomatic microscopic garnet of the grandite series in micarb chalk above basalt from the southwest branch of the Indian Ocean Ridge is described. The physical parameters $(a=$ $11.92658 \AA$, Sp. G. $=3.54, n=1.764)$ and chemical analysis are given, and the composition of the garnet is discussed. Possible sources of the constituents and mode of formation (paragenesis) are discussed; it is considered most probable that hydrothermal emanations from the magma source below the basalt transported silica, alumina, and ferric iron oxide into the ooze above it.
\end{abstract}

\section{INTRODUCTION}

The lower Miocene yellowish-brown semilithified calcite (micarb) chalk forming lithologic Unit 5 at Site 251 , southwest branch of the Indian Ocean Ridge, contains some $20 \mathrm{wt}$ \% microscopic garnet grains, 2 to $3 \mu$ in diameter. The lithology of the sediments forming Units 1 to 4 at Site 251 consists entirely of white, bluish-white, or yellowish nannoplankton ooze and chalk, containing between $0.5 \%$ and $11 \%$ of detrital or clay minerals (Cook, Zemmels and Matti, this volume, Chapter 24). Usually as much as $98 \%-99 \%$ calcium carbonate is present. Burrows, mottling, and framboidal and finely disseminated pyrite are common in the ooze and chalk (Criddle, this volume, Chapter 26).

Unit 5, comprising the base of Core 28 and all of Core 29 , overlying basement basalt, contains virtually no mineral other than recrystallized calcite and garnet. The latter was detected, and, subsequently, repeatedly confirmed, by X-ray diffractometry and powder photographs. Under high power the garnets are clearly visible in smear slides (Plate 1).

In this paper, the chemistry and physical parameters of the garnets are reported and their paragenesis discussed.

Although the garnets are believed to be metasomatic, they must be considered in the context of authigenesis, in which such an occurrence is extremely rare or even unique. Authigenic garnets may be present in the Green River Formation, the mineralogy of which has been described (cf. Milton et al., 1960). Kennan (1972) described some unusual hollow, ellipsoidal clusters formed of manganiferous garnet. The clusters occur in thin layers $(<20 \mathrm{~mm})$ within pelitic and semipelitic schists of the garnetiferous beds forming part of the aureole of the Leinster Granite. The garnets are thought to have been formed by the reconstitution of original sedimentary concretions. Donnelly and Nalli (1973) describe two occurrences of garnet in sediments from the Caribbean sampled on Leg 15 of the Deep Sea Drilling Project. One of these, considered by Donnelly and Nalli to be authigenic, consists of rectangular plates, $20 \mu$ or more across, of golden brown garnet, apparently spessartine (Site 146). The second occurrence, at Site 153, is of brownish dodecahedrally modified octahedral grains, generally less than $10 \mu$ across, in a single smear slide; such crystals are rare among garnets. This occurrence more closely resembles the Site 251 garnet, but, unfortunately, further garnets could not be located in the surrounding sediment, and the X-ray data on grains from the smear slide were not conclusive. It is tentatively suggested that the mineral is garnet and possibly of volcanic origin. The present authors have failed to find any other reported occurrences of authigenic or sedimentary metasomatic garnets. Those in ancient sediments are always of metamorphic origin; contact and regional metamorphism account for the vast majority of all garnet occurrences. A few are of igneous origin, including pegmatitic occurrences. Metasomatic garnets, as commonly defined, include, for example, andradites in skarns and hydrogrossulars in rodingites. It is this latter type of occurrence that is considered most nearly comparable with the Site 251 example; the analogy is discussed in a later section. Further points of comparison derive from synthetic garnets, some of which may grow under conditions closely resembling those at Site 251 .

\section{PHYSICAL PARAMETERS}

The garnet crystals are dodecahedral (Plate 2), possibly with icositetrahedral modifications, and average 2 to $3 \mu$ across; they may range up to $4.5 \mu$ and down to $1.5 \mu$. They show considerable intergrowths. Zabiński (1966, p. 32) observes that hydrogarnets are characteristically octahedral. Despite their very small size, it is possible to see opaque inclusions within some of the garnets: possibly such material acted as minute nuclei. In color, they are pale honey yellow. The X-ray pattern shows very well-crystallized material. Their physical parameters are

$a=11.9265 \AA \pm 0.0015$ (minor phase with $a=$ $11.992 \AA \pm 0.002) ; n=1.764 \pm 0.005 ; \mathrm{Sp} . \mathrm{G}=3.54$. Winchell's (1958) chart does not accommodate these parameters.

The presence of a minor phase with a longer cell edge is probably due to minor chemical fluctuations in the 
constituents available at the time of growth; a similar phenomenon has been observed to be common in the spinels of the hornblende mylonitized peridotites from the Saint Paul Rocks (unpublished data).

\section{CHEMISTRY}

The garnet analysis given in Table 1 (Analysis 1) was the third chemical analysis made on material separated from the core, two previous analyses carried out on the acid-insoluble residue having shown an excess of silica (about $8 \%$ by weight) which is inconsistent with a garnet formulation. This was thought to be due to contamination of the residual garnet grains by colloidal silica released during dissolution of the matrix. In view of this, the final separation used for the reported analysis was made by dissolving the matrix in $4 M$ hydrochloric acid and warming for $30 \mathrm{~min}$ in a water bath to ensure dissolution of all carbonate material. The insoluble residue was washed free of calcium salts with water and then treated with portions of hot, $2 \%$ (by weight) sodium carbonate solution to dissolve any adsorbed colloidal silica. After each treatment the insoluble residue was separated and the supernatant liquid tested colorimetrically for silica (by the reduced molybdenum blue complex method [Jeffery and Wilson, 1960]). The treatment was repeated until all silica had been removed.

In order to confirm that the above treatment had no adverse leaching effect on the grains of garnet, a finely ground sample ( $<100$ mesh) of garnet of known composition was reanalyzed after being treated with the same acid and sodium carbonate solutions. Ground olivine was added to the control garnet to simulate the liberation of colloidal silica from the core. Comparison of the analyses before and after treatment showed that the addition of olivine had no effect on the subsequent analysis of the garnet. It would appear, therefore, that this method is effective in decontaminating such a sample. Some $8 \%$ (by weight) of crystalline quartz known to be present as inclusions in the control garnet was not affected.

The analyses were made on material dried at $110^{\circ} \mathrm{C}$ and checked by X-ray powder photograph to be virtually pure. Silica was determined spectrophotometrically on a sodium hydroxide fusion of $1 \mathrm{mg}$ of material (Shapiro and Brannock, 1962); the $\mathrm{Fe}^{3+} / \mathrm{Fe}^{2+}$ ratio was determined by dissolution of a further $1 \mathrm{mg}$ of material under an atmosphere of nitrogen using the dipyridyl complex (Riley and Williams, 1959). The remaining major constituents were determined by atomic absorption spectroscopy on a lithium metaborate fusion of $5 \mathrm{mg}$ of material, fusion being followed by dissolution of the fusion cake in dilute nitric acid (Suhr and Ingammells, 1966), using standards as suggested by Abbey (1968). Unfortunately, water $\left(\mathrm{H}_{2} \mathrm{O}^{+}\right)$ could not be determined because of the very limited amount of material available.

\section{COMPOSITION OF THE GARNETS}

Calculation of the garnet formula (Table 1) reveals a deficiency in the trivalent group $\left(\mathrm{A} 1, \mathrm{Fe}^{3+}, \mathrm{Ti}\right)$ and an excess of silicon and calcium. This tendency is more common among hydrogrossular garnets than among grossular garnets and andradites. In the absence of a
TABLE 1

Chemical Analysis of the Garnet from Site 251, with Comparisons

\begin{tabular}{|c|c|c|c|}
\hline & $1^{a}$ & $\mathrm{~A}^{\mathrm{b}}$ & $\mathrm{B}^{\mathrm{c}}$ \\
\hline $\mathrm{SiO}_{2}$ & 38.18 & 36.92 & 34.01 \\
\hline $\mathrm{TiO}_{2}$ & 0.42 & 0.12 & 0.12 \\
\hline $\mathrm{A}_{2}{ }_{2} \mathrm{O}_{3}$ & 11.89 & 12.47 & 8.45 \\
\hline $\mathrm{Cr}_{2} \mathrm{O}_{3}$ & 0.01 & - & 0.20 \\
\hline $\mathrm{Fe}_{2} \mathrm{O}_{3}$ & 11.69 & 14.14 & 18.28 \\
\hline $\mathrm{FeO}$ & 0.64 & 1.84 & 1.72 \\
\hline $\mathrm{MnO}$ & 0.26 & 0.95 & 0.12 \\
\hline $\mathrm{MgO}$ & 1.47 & - & 9.96 \\
\hline $\mathrm{CaO}$ & 34.87 & 33.63 & 21.47 \\
\hline $\mathrm{Na}_{2} \mathrm{O}$ & 0.10 & - & 0.30 \\
\hline $\mathrm{K}_{2} \mathrm{O}$ & 0.02 & - & 0.10 \\
\hline $\mathrm{H}_{2} \mathrm{O}^{+}$ & n.d. ${ }^{\mathrm{d}}$ & - & 5.29 \\
\hline $\mathrm{H}_{2} \mathrm{O}^{-}$ & nil & 0.57 & 0.18 \\
\hline Total & 99.55 & 100.64 & 100.20 \\
\hline$n$ & 1.764 & 1.801 & \\
\hline Sp. G. & 3.54 & 3.71 & \\
\hline$a(\AA)$ & 11.9265 & 11.94 & 12.063 \\
\hline
\end{tabular}

Numbers of Ions on the Basis of 24 Oxygens

\begin{tabular}{|c|c|c|c|c|c|c|}
\hline $\mathrm{Si}$ & 6.04 & \multirow{3}{*}{6.04} & 5.89 & \multirow{3}{*}{6.00} & 5.06 & \multirow{3}{*}{6.37} \\
\hline $\mathrm{OH} / 4$ & -1 & & - & & 1.31 & \\
\hline A1 & - & & 0.11 & & - & \\
\hline A1 & 2.22 & \multirow{4}{*}{3.66} & 2.24 & \multirow{4}{*}{3.95} & 1.48 & \multirow{4}{*}{3.56} \\
\hline $\mathrm{Cr}$ & - & & - & & 0.02 & \\
\hline $\mathrm{Fe}^{3+}$ & 1.39 & & 1.70 & & 2.05 & \\
\hline $\mathrm{Ti}$ & 0.05 & & 0.01 & & 0.01 & \\
\hline $\mathrm{Mg}$ & 0.35 & \multirow{5}{*}{6.42} & - & \multirow{5}{*}{6.12} & 2.21 & \multirow{5}{*}{5.96} \\
\hline $\mathrm{Fe}^{2+}$ & 0.09 & & 0.24 & & 0.21 & \\
\hline $\mathrm{Mn}$ & 0.03 & & 0.13 & & 0.02 & \\
\hline $\mathrm{Ca}$ & 5.91 & & 5.75 & & 3.42 & \\
\hline $\mathrm{Na}+\mathrm{K}$ & 0.04 & & - & & 0.10 & \\
\hline Almandine & 1.5 & & 4.0 & & 3.6 & \\
\hline Andradite & 39.4 & & 41.9 & & 52.6 & \\
\hline Grossular & 52.1 & & 52.0 & & 5.6 & \\
\hline Pyrope & 6.3 & & - & & 37.6 & \\
\hline Spessartine & 0.6 & & 2.1 & & 0.3 & \\
\hline Uvarovite & - & & - & & 0.3 & \\
\hline
\end{tabular}

${ }^{\mathrm{a}}$ Garnet, Sample 251A-29-2, 130-132 cm. Anal: A. J. Easton.

${ }^{b}$ Grossular, South Africa (Clark 1957). Anal: J. Ito.

Hydrougrandite, Hsiaosungshan (Tsao-Yung-Lung, 1964).

dot determined.

water determination and in view of the excess silica, it is considered that the Site 251 garnet is more likely to be an anhydrous member of the hydrogarnet series than a (possibly slightly hydrous) member of the anhydrous series. As discussed in the final section of this report, the latter situation would be more difficult to explain than the occurrence of a hydrogarnet. For comparison, 
therefore, analyses of a grossular (Analysis A) and a hydrougrandite (Analysis B) are given in Table 1.

The calculated end-member composition of the Site 251 garnet is approximately (Gross2 $\mathrm{And}_{40} \mathrm{Py}_{6} \mathrm{Alm}_{2}$ ), for which the theoretical physical parameters are $a=$ 11.90A; $n=1.80$; and Sp.G. = 3.71 (Deer et al., 1962).

Specific gravity, as determined, is considered low possibly because of inclusions and experimental inaccuracy due to the small size of the garnets. For a composition close to the Site 251 garnet (Gross2 $\mathrm{And}_{42} \mathrm{Alm}_{4} \mathrm{Sp}_{2}$ ) Clark (1957) gives a specific gravity of 3.71 .

\section{PARAGENESIS}

As stated in the Introduction, the Site 251 occurrence of andraditic grossular garnet may be unique. An explanation of the paragenesis cannot therefore draw on preexisting theories and must answer two major questions: (1) the origin of the components $\left(\mathrm{SiO}_{2}\right.$, $\mathrm{Al}_{2} \mathrm{O}_{3}$, and $\mathrm{Fe}_{2} \mathrm{O}_{3}$, with lesser amounts of $\mathrm{TiO}_{2}, \mathrm{FeO}$, and $\mathrm{MnO}$ ), considerable quantities of which must have been introduced into a wet carbonate mud (calcium carbonate with very minor magnesium carbonate), where a high proportion reacted and crystallized to form some $20 \mathrm{wt}$ \% garnet in the ooze; (2) the physical conditions, especially pressure and temperature, under which the garnets, once nucleated, were able to grow.

The garnets are found in a zone of ooze, recrystallized into calcite (micarb) chalk, from 0 to 18.3 meters above the underlying basement basalt. If they grew as a result of reaction between wet lime and included colloidal $\mathrm{SiO}_{2}, \mathrm{Al}_{2} \mathrm{O}_{3}$, and $\mathrm{Fe}_{2} \mathrm{O}_{3}$, this boundary would not be sharp, and the garnets would be spread diffusely over a considerable depth. It therefore seems reasonably certain that the source of the metasomatic material was the magma chamber below the basalt, from which alkaline hydrothermal fluids emanated, traveling to the basalt surface through cracks, veins, and fissures, and, possibly, intergranular pore spaces. These fluids either carried the components $\left(\mathrm{SiO}_{2}, \mathrm{Al}_{2} \mathrm{O}_{3}, \mathrm{Fe}_{2} \mathrm{O}_{3}\right.$, etc.) or leached them deuterically from the basalt and subsequently conveyed them to the basalt surface. Since the stratigraphic limit of garnet growth is the upper limit of Unit 5 (the recrystallized and semilithified pale yellowish-brown calcite [micarb] chalk), it is considered that at the time of the hydrothermal event the upper boundary of Unit 5 probably represented the watersediment interface or sea floor. As a result, the limited volume of ooze behaved as a closed system within which unlimited diffusion could take place. The age of the upper boundary of Unit 5 could be some 10 or 20 m.y. younger than that of the basalt (estimated from paleontological and $\mathrm{K} / \mathrm{Ar}$ ages). The hydrothermal fluids recrystallized the ooze into calcite (micarb) chalk and enriched it somewhat with iron (iron content $=3 \%$ ), compared with the 468 meters of overlying unaltered nannoplankton chalks and oozes (average iron content $=1.1 \%)($ Fleet and Kempe, this volume, Chapter 21$)$. It is interesting to consider the possibility that, although the iron enrichment is small compared with that in the iron-rich basal sediments from eastern Pacific Ocean (iron content up to $20 \%$ ) described by Boström and Peterson (1966) and Cronan et al. (1972), and ascribed to the hydrothermal leaching of newly extruded basalt, formation of the garnets may represent an alternative hydrothermal process to "umber" formation and must almost certainly take place in other basal carbonate sediments.

Alternative suggestions, however, proposed by A. J. Horowitz (personal communication), are that the micarb chalk might be authigenic, precipitated directly from the heated sea-water at the time of extrusion of the basalt. Or, again, that the micarb chalk might represent the sediment present, as ooze, at the time of extrusion of the basalt; the latter would then be analogous with an intrusive sill, and could have baked the ooze into its present form.

If the metasomatic components derive from the basalts themselves, they must be extracted either by leaching or by deuteric decomposition of the basalt to the extent that the resulting material is able to disperse, possibly by convection, through the overlying ooze. The first suggestion would be substantiated if the altered basalt could be shown to be significantly depleted in $\mathrm{SiO}_{2}, \mathrm{Al}_{2} \mathrm{O}_{3}$, and $\mathrm{Fe}_{2} \mathrm{O}_{3}$. Such depletion could not, however, be considered as proof since alteration may result in such depletion of the basalt, with other gains and losses, without growth of garnet in the overlying sediment. In Table 2, three analyses of fresh, intermediate, and, as near as possible, "contact" basalt are given (Kempe, this volume, Chapter 14). It can be seen that, in fact, the intermediate basalt is more highly altered than the "near contact" sample. Although its water content is slightly lower, it shows greater loss in $\mathrm{CaO}$ and $\mathrm{MgO}$ and gain in $\mathrm{K}_{2} \mathrm{O}, \mathrm{TiO}_{2}$, and total iron (Hart, 1970). It also shows a greater $\mathrm{Fe}_{2} \mathrm{O}_{3} / \mathrm{FeO}$ ratio. So far as the garnet components are concerned, there is clearly no correlation. Silica is depleted but total iron is enriched; alumina is also enriched, although depleted in the "near contact" rock.

If the metasomatic material derives directly from decomposition, it is worth considering the proposition that an analysis of palagonite from Swallow Bank, North Atlantic Ocean (Matthews, 1971, p. 564) will (if the alkalis, phosphorus, water, and other volatiles are replaced by lime) calculate to a very close approximation to the Site 251 garnet (Table 2). Palagonite represents sideromelanic glass typical of surface pillows of a ridge basalt altered by hot exotic water. Such glass is known to have been extruded at the basement contact at Site 251 (Kempe, Chapter 14, this volume). Similar replacement and calculation of the analyzed basalt Sample 251A-31-1, 39-41 cm, gives a much less satisfactory result. It is tempting to speculate, therefore, whether decomposition of palagonite formed from volcanic glass, rather than decomposition of crystalline basalt, could lead to the formation of the garnets. A further possibility is that decomposition could come about as a direct result of reaction with seawater upon extrusion (Hart, 1973, p. 77). However, it must be stressed that total decomposition or active leaching of the basalt is necessary to obtain the required components. Deuteric alteration or reaction with seawater, while producing very considerable changes in the chemistry of the basalt or basaltic glass, will 
TABLE 2

Basalt and Palagonite Analyses from Site 251 and Swallow Bank, Atlantic Ocean, with Two Analyses Recast as Garnet Compositions

\begin{tabular}{|c|c|c|c|c|c|c|c|c|}
\hline & $\mathrm{A}^{\mathrm{a}}$ & $\mathrm{B}^{\mathrm{b}}$ & $\mathrm{C}^{\mathrm{c}}$ & $B^{\prime d}$ & $1^{\mathrm{e}}$ & $D^{\prime f}$ & $\mathrm{D}^{\mathrm{g}}$ & $\mathrm{E}^{\mathrm{h}}$ \\
\hline $\mathrm{SiO}_{2}$ & 50.37 & 45.68 & 45.89 & 45.68 & 38.18 & 41.96 & 41.96 & 47.44 \\
\hline $\mathrm{TiO}_{2}$ & 1.60 & 1.78 & 1.47 & 1.78 & 0.42 & 1.63 & 1.63 & 1.88 \\
\hline $\mathrm{A}_{2}{ }_{2} \mathrm{O}_{3}$ & 14.60 & 15.65 & 13.44 & 15.65 & 11.89 & 16.06 & 16.06 & 15.58 \\
\hline $\mathrm{Fe}_{2} \mathrm{O}_{3}$ & 1.70 & 8.05 & 6.77 & 13.95 & 11.69 & 9.39 & 9.39 & 10.52 \\
\hline $\mathrm{FeO}$ & 8.74 & 5.31 & 5.14 & - & 0.64 & nil & nil & 0.68 \\
\hline $\mathrm{MnO}$ & 0.17 & 0.18 & 0.18 & 0.18 & 0.26 & 0.08 & 0.08 & 0.15 \\
\hline $\mathrm{MgO}$ & 7.13 & 4.88 & 7.43 & 4.88 & 1.47 & 3.69 & 3.69 & 2.89 \\
\hline $\mathrm{CaO}$ & 10.84 & 10.96 & 11.48 & 19.07 & 34.87 & 27.30 & 1.49 & 6.87 \\
\hline $\mathrm{Na}_{2} \mathrm{O}$ & 2.67 & 2.58 & 2.57 & - & 0.10 & - & 1.82 & 2.94 \\
\hline $\mathrm{K}_{2} \mathrm{O}$ & 0.12 & 0.60 & 0.30 & - & 0.02 & - & 3.48 & 2.96 \\
\hline $\mathrm{H}_{2} \mathrm{O}^{+}$ & 0.90 & 1.16 & 1.47 & - & n.d. ${ }^{\mathrm{i}}$ & - & 6.34 & 2.35 \\
\hline $\mathrm{H}_{2} \mathrm{O}^{-}$ & 0.62 & 1.95 & 2.17 & - & nil & - & 13.99 & 4.90 \\
\hline $\mathrm{P}_{2} \mathrm{O}_{5}$ & 0.15 & 0.27 & 0.16 & - & - & - & 0.01 & 0.28 \\
\hline $\mathrm{CO}_{2}$ & 0.23 & 1.53 & 1.60 & - & - & - & nil & 0.73 \\
\hline Others & 0.16 & 0.02 & 0.01 & - & - & - & 0.17 & 0.09 \\
\hline Total & 100.00 & 100.60 & 100.08 & 101.19 & 99.54 & 100.11 & 100.11 & 100.26 \\
\hline
\end{tabular}

Numbers of Ions on the Basis of 24 Oxygens

\begin{tabular}{lrrc}
\hline $\mathrm{Si}$ & 6.63 & 6.04 & 6.29 \\
$\mathrm{~A} 1$ & - & - & - \\
$\mathrm{A} 1$ & 2.68 & 2.22 & 2.84 \\
$\mathrm{Fe}^{3+}$ & 1.53 & 1.39 & 1.06 \\
$\mathrm{Ti}$ & 0.20 & 0.05 & 0.18 \\
$\mathrm{Mg}$ & & & \\
$\mathrm{Fe}^{2+}$ & 1.06 & 0.35 & 0.82 \\
$\mathrm{Mn}$ & - & 0.09 & - \\
$\mathrm{Ca}$ & 0.02 & 0.03 & 0.01 \\
& 2.97 & 5.91 & 4.37 \\
Almandine & & & \\
Andradite & - & 1.5 & - \\
Grossular & 64.2 & 39.4 & 38.0 \\
Pyrope & 9.1 & 52.1 & 51.3 \\
Spessartine & 26.2 & 6.3 & 10.4 \\
\hline
\end{tabular}

${ }^{\mathrm{a}}$ Fresh basalt, southwest branch, Indian Ocean Ridge, Sample 251A-31-4, 29-31 cm (Kempe, Chapter 14, this volume). Anal: C.J. Elliott and V.K. Din.

${ }^{\mathrm{b}}$ Altered intermediate basalt, Sample 251 A-31-1, 39-41 cm (Kempe, Chapter 14, this volume). Anal: V. K. Din.

cAltered "near contact" basalt, Sample 251A-30-1, 140-145 cm (Kempe, Chapter 14, this volume). Anal: V. K. Din.

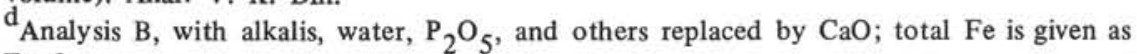
$\mathrm{Fe}_{2} \mathrm{O}_{3}$.

${ }^{\mathrm{e}} \mathrm{Garnet}$ (Table 1, Analysis 1). Anal: A.J. Easton.

${ }^{\mathrm{f}}$ Analysis $\mathrm{D}$, with alkalis, water, $\mathrm{P}_{2} \mathrm{O}_{5}$, and others replaced by $\mathrm{CaO}$.

galagonite, Swallow Bank (Matthews, 1971, Table 3, p. 564). Anal: W. H. Herdsman. h Typical basalt, Swallow Bank (Matthews, 1971, Table 3, p. 564). Anal: W. H. Herdsman. ${ }^{\mathrm{i}}$ Not determined. 
probably result in net gains to the basalt in iron, either gains or losses in alumina, and rather limited losses in silica (Hart, 1970).

The answer to the second question - the physical conditions of formation of the garnets - is far more difficult to obtain. As stated earlier, no previous comparable parageneses are known, and the most common general paragenesis for garnets, metamorphism, is precluded for lack of metamorphic temperatures and pressures. Only rodingites and synthetic garnets are available for comparison. Rodingites are generally considered to result from metasomatic alteration of gabbroic rock during the serpentization of the enclosing ultramafic country rock. Such hydrothermal attacks on gabbroic rocks release and hold silica and alumina; they will also release and hold lime, which may or may not be supplemented from an external source (de Waal, 1969). Silica tends to be deficient in such basic to ultrabasic rocks and hydrogrossular garnet, in which $(\mathrm{OH}) / 4$ replaces silicon, is the main newly crystalline phase, often accompanied by the magnesium silicate, idocrase. Idocrase may also occur as an impurity in the hydrogrossular. Temperatures and pressures are relatively low, and hydrogarnet is known to be far more common than the anhydrous species. Nevertheless, grossular has been reported (Zabiński, 1966) and possibly, as may be the case with the Site 251 garnets, nearly anhydrous members of the hydrogarnet series are fairly common in rodingitic parageneses.

Synthetic garnets have largely been high temperature species, many of them gem varieties (cf. Nassau, 1972). Webster (1970) reviewed the range of rare earths and other trace elements (which include vanadium, zirconium, germanium, yttrium, and scandium) used in these garnets. Isaacs (1965) synthesized uvarovite in order to study its relationship with grossular and andradite. However, garnet syntheses, reviewed by Zabiński(1966, p. 55), include low-temperature examples. Zabiński also mentions that hydrogrossular is among the resultant products of the hydration of Portland cement. Clay reactions with alkali solutions producing hydrogarnets have been described by Krönert et al. (1964) and Iwamoto and Sudo (1965). Krönert et al. found that clay mixtures, including kaolinite, montmorillonite, and illite, reacted with calcium hydroxide to give products that included hydrogrossular, a process important in soil stabilization. Iwamoto and Sudo heated aluminous clays, some containing magnesium, with calcium carbonate and ammonium chloride for $1 \mathrm{hr}$, at atmospheric pressure, at $500-1000^{\circ} \mathrm{C}$. Without the aluminum chloride, the temperature of reaction rose higher, suggesting that the hydrogen in the $\mathrm{NH}_{4}{ }^{+}$cations may help in the formation of hydrogarnet. Midgley and Chopra (1960) found hydrogarnet among the products when lime and slag glass aggregate were autoclaved at $188^{\circ} \mathrm{C}$ for between 2 and $48 \mathrm{hr}$ at 11 bars.

Following Yoder's (1950) attempts to synthesize grossular, Roy and Roy (1960) set out to investigate the possibility of a complete solid solution series between grossular and hydrogrossular, as suggested by Yoder's work, and the effects of time, temperature and pressure upon the stability of the phases. Roy and Roy's study showed a number of experimental facts: for example, it is usually assumed, when a hydrogrossular forms from a total grossular starting composition silica has been leached out. Their hermetically sealed systems gave similar products and disproved the suggestion. They also showed that gels yield more nearly anhydrous garnets than do glasses when used as starting materials.

Using the grossular composition, in runs of (usually) at least one week and pressures of 2000 bars, they obtained essentially pure grossular, with negligible water content, between $860^{\circ}$ and $550^{\circ} \mathrm{C}$; a solid solution series from pure grossular $\left(\mathrm{Ca}_{3} \mathrm{Al}_{2} \mathrm{Si}_{3} \mathrm{O}_{12}\right)$ to $\mathrm{Ca}_{3} \mathrm{Al}_{2} \mathrm{Si}_{2.75} \mathrm{O}_{11}(\mathrm{HO})$, probably metastable, at intermediate temperatures $\left(300-600^{\circ} \mathrm{C}\right)$; and a stable low temperature series from pure "hydrogarnet" $\left(\mathrm{Ca}_{3} \mathrm{Al}_{2}(\mathrm{HO})_{12}\right)$ to about $\mathrm{Ca}_{3} \mathrm{Al}_{2} \mathrm{Si}_{2} \mathrm{O}_{8}(\mathrm{OH})_{4}$ at $360^{\circ}$ to $300^{\circ} \mathrm{C}$. Thus it was shown that grossulars containing a little water are probably metastable, since anhydrous grossular can form at temperatures at least as low as $600^{\circ} \mathrm{C}$, needing only water to catalyze its formation; at lower temperatures $\left(550^{\circ}\right.$ to $\left.400^{\circ} \mathrm{C}\right)$ garnets with slightly expanded lattices may form. The earlier confusion, the authors conclude, over the formation of hydrogrossulars from the pure grossular composition is shown to be due to failure to attain equilibrium.

Lastly, and most relevant, Ito and Frondel (1967) produced a series of hydrogarnets from the appropriate gels and silicon-deficient aqueous sodium hydroxide solutions at a $\mathrm{pH}$ of 13.5 . The mixture, at 1 bar, was boiled for $10 \mathrm{~min}$ at $105^{\circ} \mathrm{C}$ and subsequently held at $85^{\circ} \mathrm{C}$ for periods of between 1 and 3 days. Nucleation began during the initial boiling, with the formation of a bulky precipitate which gradually coarsened and settled out. The garnets were centrifuged without washing and air dried at $120^{\circ} \mathrm{C}$. They included the species $\mathrm{Ca}_{3} \mathrm{Fe}_{2}\left(\mathrm{SiO}_{4}\right)(\mathrm{OH})$ and others in the same series, and zirconium- and titanium-bearing species. Finally, Arrhenius (1971) and L. H. Fuchs (in preparation), discussing chemical effects in plasma condensation in the context of the formation of solar system, suggest that among the final, low-temperature products of the residual ionized fraction of a condensing gaseous system would be calcium aluminum garnet containing trivalent iron, such as has been observed in some carbonaceous meteorites.

\section{SUMMARY AND CONCLUSIONS}

It is clear from synthesis experiments that garnets can form at low temperatures $\left(<100^{\circ} \mathrm{C}\right)$ and atmospheric pressure. Usually, such garnets are hydrogarnets, but Frankel (1959), and Roy and Roy (1960) quoted evidence that water can act as a catalyst to promote crystallization of even anhydrous grossular in hydrothermal transformations. An environment such as the Site 251 ooze where water is abundant but silica is also probably in excess might be ideal for such growth, in contrast with a rodingite environment where silica is markedly deficient. The Site 251 garnets, therefore, are probably anhydrous garnets containing small amounts of water, or, more likely, nearly anhydrous members of the hydrogarnet (grandite) series. The material introduced for their formation $\left(\mathrm{SiO}_{2}, \mathrm{Al}_{2} \mathrm{O}_{3}, \mathrm{Fe}_{2} \mathrm{O}_{3}\right)$ was probably transported from the magma source below the basalt in a highly alkaline hydrothermal fluid, in which 
silica would be in solution and the trivalent oxides form colloidal gels. Upon introduction into the ooze, a gelatinous $\mathrm{Ca}-\mathrm{Al}(\mathrm{Fe})$ complex may form, which, by a chemical exchange process, would lead to widespread nucleation of the garnets. Such nucleation might well be metastable, controlled by, in addition to pressure and temperature, such factors as $p \mathrm{H}$, Eh, composition and concentration of the components, and other variables affecting surface tension (Kirkinskiy, 1970). The temperature was probably rather less than $100^{\circ} \mathrm{C}$, though presumably sufficient to recrystallize the ooze into calcite (micarb) chalk, at a hydrostatic pressure of the order of 500 bars; the present pressure, in a total water plus sediment depth of about $4 \mathrm{~km}$, must be of the order of 600 bars. Zabiński concludes (1966, p. 56) that the most probable temperature range for the formation of natural hydrogarnets is 200 to $400^{\circ} \mathrm{C}$, while pressures are more difficult to assess. He suggests a relatively high partial pressure of $\mathrm{H}_{2} \mathrm{O}$, dependent to some extent on $p \mathrm{H}$ and chemical composition and considers that geological time, not available for synthetic products, may contribute substantially to natural hydrogarnet crystallization at low temperatures and pressures.

Donnelly and Nalli (1973) suggest that the spessartine in the Leg 15 sediments might be authigenic. Spessartine is indeed one of the first minerals to crystallize in low-grade metamorphic facies. The present occurrence cannot be described as authigenic since it involves metasomatism; it is, perhaps, a form of skarn. But the garnets appear to have formed under normal diagenetic conditions of pressure and temperature or, at most, those of the zeolitic facies. Zabiński (1966) sums up his considerable study of the hydrogarnets by concluding that they form and show maximum stability under conditions typical of the zeolitic and greenschist facies of regional metamorphism and of the albite-epidotehornfels contact facies; the latter two, in which temperatures in excess of $400^{\circ} \mathrm{C}$ are found, broadly mark the lower limits of stability of anhydrous garnets.

It is suggested, finally, that a search through calcite (micarb) chalks overlying basement basalt from other DSDP sites would almost certainly reveal other garnet occurrences and possibly shed more light on their mode of origin.

\section{ACKNOWLEDGMENTS}

Professor G. Arrhenius and Dr. M. H. Hey are sincerely thanked for reviewing the manuscript and making many helpful suggestions. The authors are grateful to H. A. Buckley for taking the SEM photographs and to Miss Eva Fejer for repeatedly confirming that the material under investigation and analysis was, in fact, garnet and for determining $a$.

\section{REFERENCES}

Abbey, S., 1968. Analysis of rocks and minerals by atomic absorption spectroscopy. Part 2. Determination of total iron, magnesium, calcium, sodium and potassium: Geol. Surv. Canada, Paper 68-20.

Arrhenius, G., 1971. Chemical effects in plasma condensation: Nobel Symposium 21, from plasma to planet, Proc., Saltajöbaden, p. 117.

Boström, K. and Peterson, M. N. A., 1966. Precipitates from hydrothermal exhalations on the East Pacific Rise: Econ. Geol., v. 61, p. 1258.
Clark, S. P., Jr., 1957. Absorption spectra of some silicates in the visible and near infrared: Am. Mineral., v. 42, p. 732.

Cronan, D. S., van Andel, T. H., Heath, G. Ross, Dinkelman, M. G., Bennett, R. H., Bukry, D., Charleston, S., Kaneps, A., Rodolfo, K. S., and Yeats, R. S., 1972. Iron-rich basal sediments from the eastern equatorial Pacific: Leg 16, Deep Sea Drilling Project: Science, v. 175, p. 61.

Deer, W. A., Howie, R. A., and Zussman, J., 1962. Rockforming minerals, vol. 1: London (Longmans).

de Waal, S. A., 1969. On the origin of hydrogrossularite and other calcium silicates in serpentinites: Geol. Soc. S. Africa Trans., v. 72, p. 23.

Donnelly, T. W. and Nalli, G., 1973. Mineralogy and chemistry of Caribbean sediments. In Edgar, N. T., Saunders, J. B., et al., Initial Reports of the Deep Sea Drilling Project, Volume 15. Washington (U.S. Government Printing Office), p. 929.

Frankel, J. J., 1959. Uvarovite garnet and South African jade (hydrogrossular) from the Bushveld complex: Transvaal. Am. Mineral., v. 44 , p. 565.

Hart, R. A., 1970. Chemical exchange between sea water and deep ocean basalts: Earth Planet. Sci. Lett., v. 9, p. 269. 1973. Geochemical and geophysical implications of the reaction between sea-water and the oceanic crust: Nature, v. 243 , p. 76.

Issacs, T., 1965. A study of uvarovite: Mineral. Mag., v. 35, p. 38.

Ito, J. and Frondel, C., 1967. New synthetic hydrogarnets: Am. Mineral., v. 52, p. 1105.

Iwamoto, S. and Sudo, T., 1965. Chemical reactions among clay minerals, calcium carbonate and ammonium chloride: Am. Mineral., v. 50, p. 886.

Jeffery, P. G. and Wilson, A. D., 1960. A combined gravimetric and photometric procedure for determining silica in silicate rocks and minerals: Analyst, v. 85, p. 478.

Kennan, P. S., 1972. Some curious garnet clusters from the Garnetiferous Beds of the Leinster Granite aureole: Geol. Mag., v. 109, p. 165.

Kirkinskiy, V. A., 1970. Mechanism of metastable crystallization: Dokl. Akad. Sci. U.S.S.R., Earth Sci. Sect., v. 192, p. 119.

Kronhert, W., Schwiete, H. E., and Wetzel, K., 1964. Reaktionen von Erdalkalihydroxiden mit Tonmineralien in wässriger Suspension: Naturw, v. 51, p. 381.

Matthews, D. H., 1971. Altered basalts from Swallow Bank, an abyssal hill in the NE Atlantic and from a nearby seamount: Roy. Soc. Lond., Phil. Trans., Series A, v. 268, p. 551 .

Midgley, H. G. and Chopra, S. K., 1960. Hydrothermal reactions between lime and aggregate fines: Mag. Concrete Res., v. 12, p. 73.

Milton, C., Chao, E. C. T., Fahey, J. J., and Mrose, M. E., 1960. Silicate mineralogy of the Green River formation of Wyoming, Utah and Colorado: Int. Geol. Congr. 21st, Norden, v. 21, p. 171.

Nassau, K., 1972. The state of the art - crystal growth. Part III: Min. Record, v. 3, p. 103.

Riley, J. P. and Williams, H. P., 1959. The microanalysis of silicate and carbonate minerals. 1. Determination of ferrous iron: Mikrochim. Acta, v. 4, p. 516.

Roy, D. M. and Roy, R., 1960. Crystalline solubility and zeolitic behavior in garnet phases in the system $\mathrm{CaO}-\mathrm{Al}_{2} \mathrm{O}_{3}-$ $\mathrm{SiO}_{2}-\mathrm{H}_{2} \mathrm{O}$ : Paper III-S9, Symp. Chem. Cement, 4th Internatl., Proc., Washington, D.C., p. 307.

Shapiro, L. and Brannock, W. W., 1962. Rapid analysis of silicate, carbonate and phosphate rocks: U.S. Geol. Surv. Bull. 1144-A.

Suhr, N. H. and Ingamells, C. O., 1966. Solution technique for analysis of silicates: Anal. Chem., v. 38, p. 730. 
Tsao-Yung-Lung, 1964. Hydrougrandite, a new variety of hydrogarnet from Hsiaosungsha (abstract): Acta Geol. Sinica, v. 44 , p. 228.

Webster, R., 1970. Modern synthetic gemstones: J. Gemmology, v. 12, p. 101.
Winchell, H., 1958. The composition and physical properties of garnet: Am. Mineral., v. 43, p. 595.

Yoder, H. S., 1950. Stability relations of grossularite: J. Geol., v. 58 , p. 221.

Zabiński, W., 1966. Hydrogarnets: Polska Akad. Nauk, Prace Min., v. 3, p. 3. 
PLATE 1
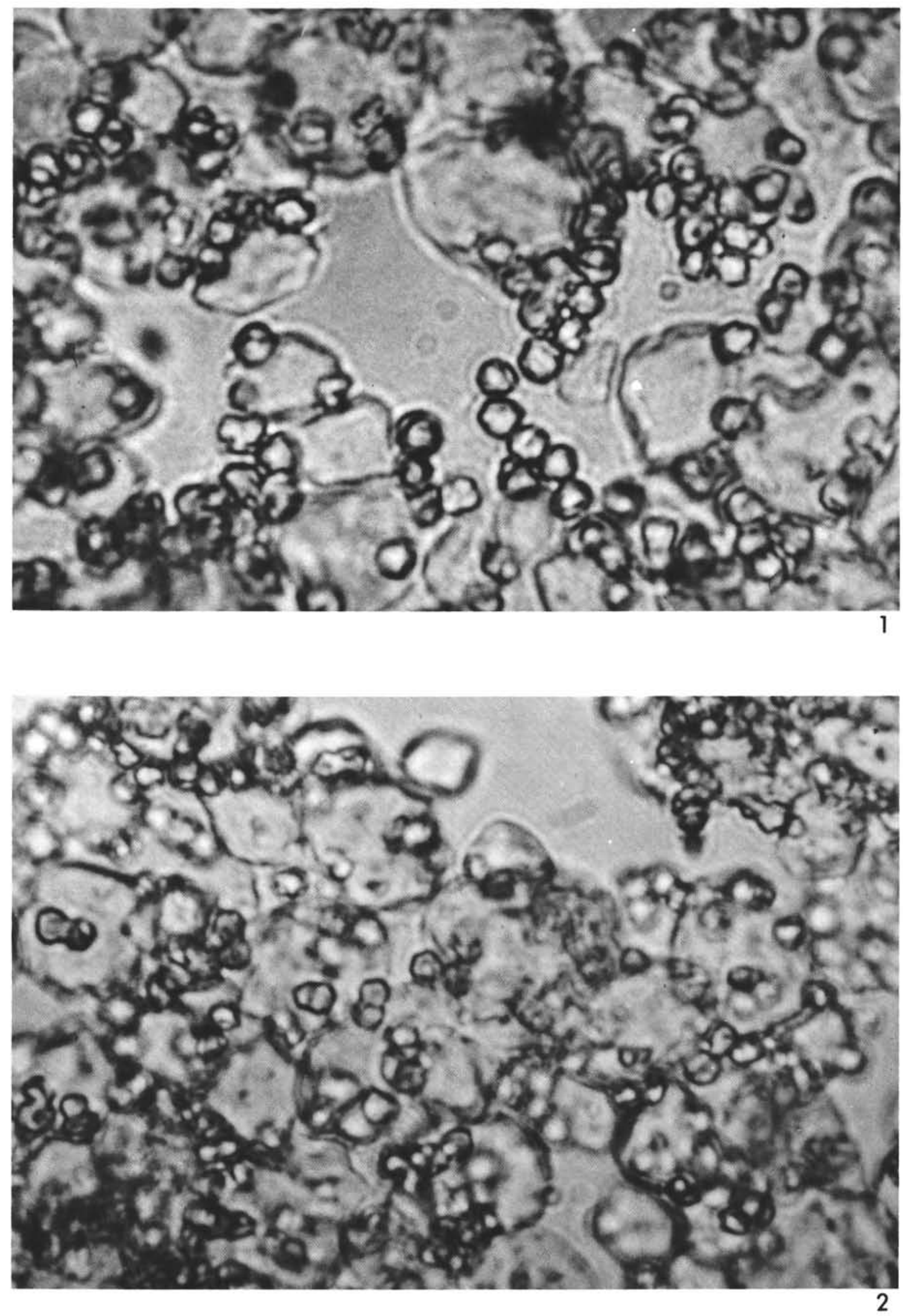

Photomicrographs (plain light, $\times 1000$ ) of the garnet-bearing calcite (micarb) chalk (Sample 251A-29-1-137). 
PLATE 2
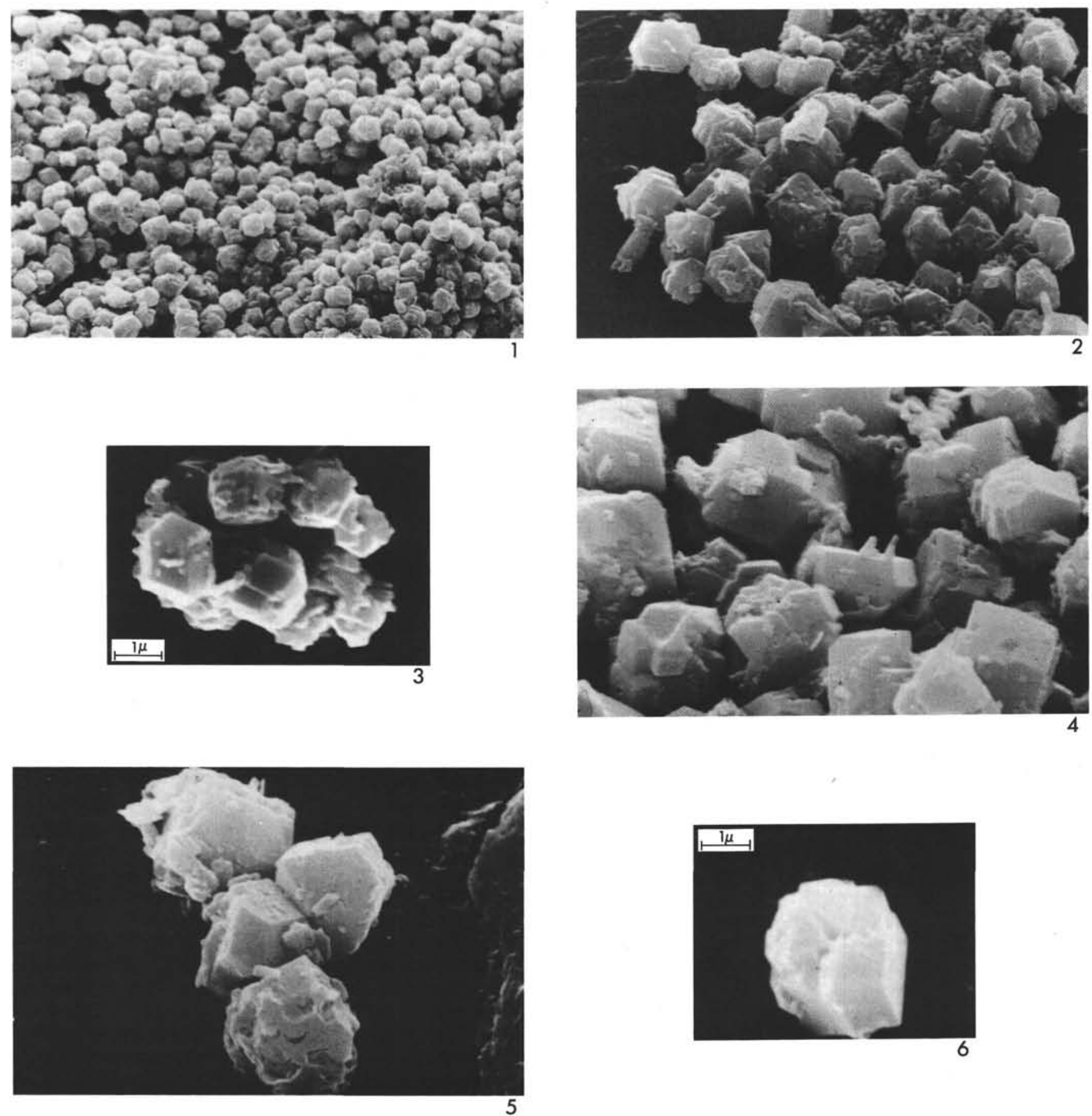

SEM photographs by H. A. Buckley of the garnets, which are mostly $2 \mu-3 \mu$ across (gold coating). 